\title{
The Development of Sugar Beet Production and Processing Simulation Model - a System Dynamics Approach to Support Decision-Making Processes
}

\author{
Črtomir Rozman" ${ }^{1 *}$, Andrej Škraba², Karmen Pažek1, Miroljub Kljajić ${ }^{2}$ \\ ${ }^{1}$ University of Maribor, Faculty of Agriculture and Life Sciences, Pivola 11, 2311 Hoče, Slovenia. \\ crt.rozman@um.si (corresponding author), karmen.pazek@um.si \\ ${ }^{2}$ University of Maribor, Faculty of Organizational Sciences, Kidričeva cesta 55a, 4000 Kranj, Slovenia, \\ andrej.skraba@fov.uni-mb.si, miroljub.kljajic@fov.uni-mb.si
}

Background: The sugar beet is the main field crop used for sugar production in the temperate climatic zone. The abolishment of the quota system will open new investment opportunities in countries that were forced to abandon sugar industry as the result of the reform in 2006. Present paper describes the modeling of sugar beet production and its processing into sugar for purpose of decision support.

Methods: A system dynamics methodology was chosen to model impacts of regional sugar factory investment. We present two basic concepts of system dynamics models at causal loop diagram level. The first holistic model deals with regional planning of new product development and the second one deals with factory model.

Results: The holistic model presented main feedback loops and dynamics of main elements in the case of regional investment into sugar industry. The factory model considered the specifics of the beet processing which is a) limited period of beet processing and b) initial adjustment to the production capacity at the start of the production season Conclusions: The model seeks answers to strategic questions related to the whole sugar beet production and processing system and will be used for simulation of different scenarios for sugar production and their impact on economic and environmental parameters at an aggregate level.

Keywords: Sugar beet, system dynamics, simulation, model

\section{Introduction}

The 2007 European Union (EU) Sugar Reform turned the EU from a major sugar exporter into a major sugar importer, significantly changing the dynamics of the EU sugar market. High international sugar prices have been undercutting the EU's attraction as a favored export destination, while the increased productivity resulting from the reform has led to record EU sugar production beyond quota (Polet, 2012).
Sugar beet is the main field crop used for sugar production in the temperate climatic zone. According to Food and Agriculture Organization data, the area under sugar beet has decreased as result of technical advances and higher yields (Steinrücken, 2005; Ćurčić et al., 2009). The expected elimination of the sugar quota system in 2017, in the final reform, presents new business opportunities for farmers and investors in countries that have abandoned sugar beet production and the sugar industry as a whole. Greater competitiveness

Received: $28^{\text {th }}$ November 2013; revised: $17^{\text {th }}$ January 2014; accepted $8^{\text {th }}$ March 2014 
and deregulation in agribusiness and the food industry require new forms of co-ordination between farmers and their clients to increase the efficiency and profitability of the supply chain. Processing firms use various co-ordination processes to control the quantity and quality of their raw material (Gaucher et al., 2003). Since the investments in the sugar industry are long-term and financially demanding, there is a clear need for the use of modern decision support tools and models in order to ensure good decision support before the investment is made (Rozman et al., 2013).

According to Vandendriessche and Van Ittersum (1995), models for the sugar beet crop have been developed for a variety of purposes: (i) sugar yield forecasting with regard to campaign planning and marketing strategies; (ii) integration of scientific knowledge and hypothesis testing; and (iii) decision support, particularly in tactical and operational decisions at the farm level. It is difficult to satisfy these three objectives with one model; each aim requires its own model. Available sugar beet models can be divided into two types, descriptive and explanatory, and they integrate various processes. The former type is primarily used for prediction, the latter for research. For decision support and the management of a sugar beet crop at the farm level, a combination of descriptive or explanatory crop models, databases, and expert systems may be used.

A variety of models are used for decision support or forecasting in sugar beet production and processing. For example, Jones et al. (2003) studied the impact of future climate change on sugar beet yields over Western Europe using future (2021-2050) climate scenario data from a general circulation model, and the Broom's Barn simulation model of rain-fed crop growth and yield. Tzilivakis et al. (2005) assessed 13 sugar beet production scenarios that represent those used throughout the UK. They differed in soil type, nutrients applied (inorganic and organic), crop protection (chemical and cultural), and use of irrigation. The assessment included an evaluation of inputs (nutrients, pesticides, and energy) and their impact on the environment. A net margin for each scenario was also calculated to provide an economic assessment. Gohin and Bureau (2006) simulated the effects of the 2006 reform of the EU sugar regime and the effects of a ban on sugar export subsidies with the use of the general equilibrium model.

Stöckle et al. (2003) presented CropSyst as a multiyear, multi-crop, daily time step cropping systems simulation model developed to serve as an analytical tool to study the effect of climate, soils, and management on cropping systems productivity and the environment. CropSyst simulates the soil, water, and nitrogen budgets, crop growth and development, crop yield, residue production and decomposition, soil erosion by water, and salinity.

Models of sugar factories have also been developed. Henke et al. (2006) described the application of the Sugars ${ }^{\mathrm{TM}}$ program for modeling and simulation of a sugar factory with subsequent production of bioethanol and ani- mal fodder. The designed scheme was further adjusted and verified using data from the Czech sugar industry (i.e., processing of 10.000 tons of sugar beet per day, $17 \%$ of sucrose in sugar beet, $2.5 \%$ of impurities, and $98 \%$ effectiveness of ethanol fermentation).

Rozman et al. (2013) developed a spreadsheet technologic economic model for feasibility analysis of the sugar beet plant. This model is used for the (1) assessment of sugar beet production costs, (2) sugar beet processing costs and factory cash flow projections, and (3) complete analysis of required field area necessary for the planned sugar factory.

System dynamics (SD) is one of the possibilities for employing computer simulation in order to support the decision-making process in sugar beet processing (Forrester, $1958,1994)$. The system dynamics was successfully applied in several similar cases (Rehan et al., 2014; MartinezMoyano and Richardson, 2014; Rozman et al., 2013). This paper discusses the problem of sugar beet processing using causal loop diagram (CLD) and SD methodology for holistic decision support.

\section{System approach to regional planning of new product development}

As stated in the introduction, investment in a new factory may have many advantages for a region; tradition, culture, land availability, and unemployment. However, due to the effects of the financial crisis and ecology sensitivities on the investment impact on ecology, a local authority must consider a number of factors, not only economics, in planning future development. Therefore, we decided to use SD methodology for such analyses, as one powerful method of decision support. Figure 1 shows a causal loop diagram (CLD) of a new sugar production factory with all relevant implications for development in the region.

We can observe several main feedback loops reinforcing and balancing in Figure 1. The reinforcing loops R1, R2, $\mathrm{R} 3$, and R4 are typical developmental loops. The investment in sugar production represents a new employment opportunity and increases workforce demand. That means that investment in the sugar factory, and power from the electrical biogas-based power plant, provides new employment opportunities and workforce demand in the sugar production and electrical plant sectors, which, at some time following investment, makes a final impact on regional development. This is also expressed in the demand for special agricultural custom machine services, such as sugar-beet harvesting, cleaning-loading, and transport. The sugar industry also contributes to employment in other sectors that support the sugar industry with production inputs (such as use of lime and fuel), as well as input for sugar beet production in the 


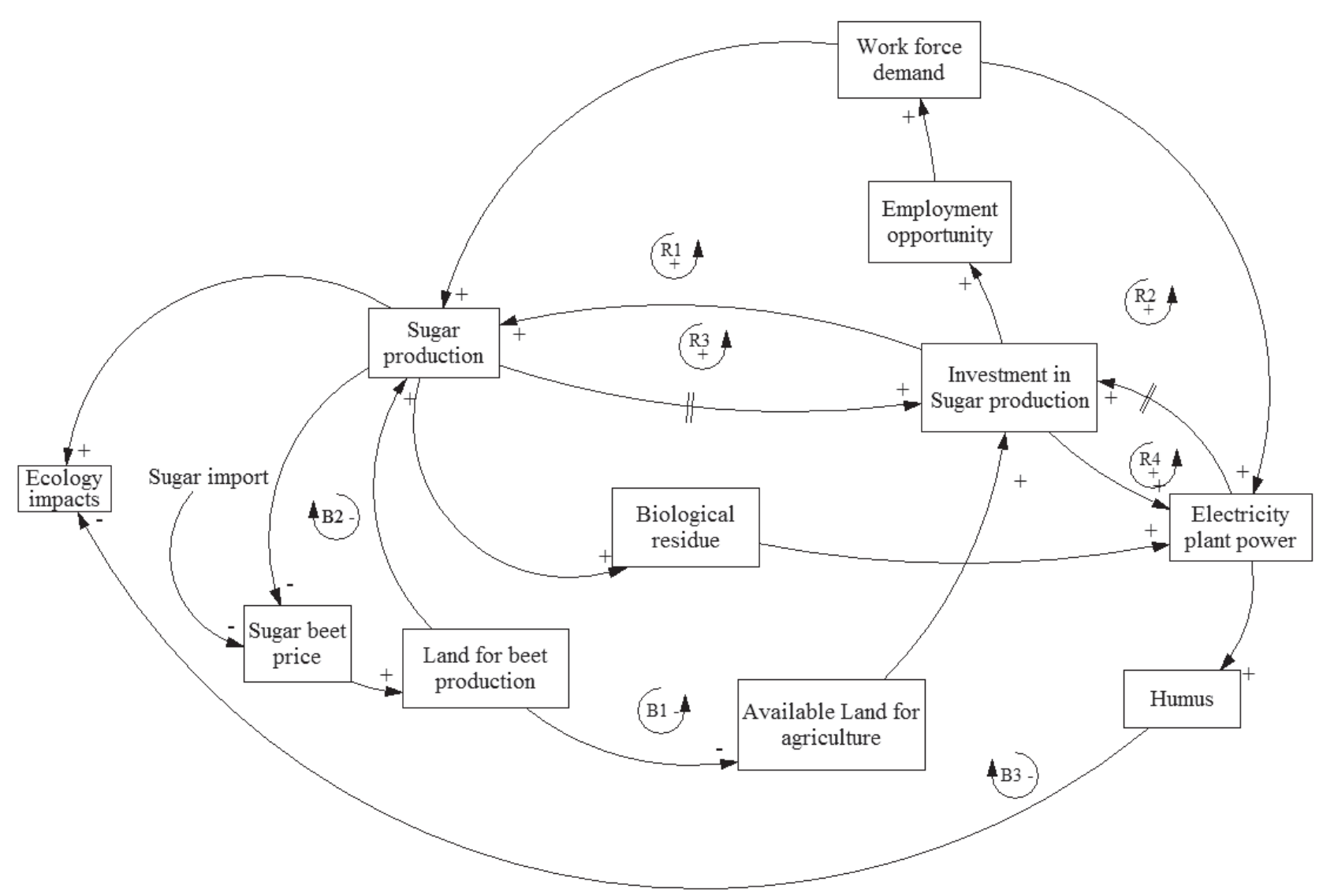

Figure 1: Holistic model of regional development of new product (sugar)

field. According to Rozman et al. (2013), a factory with a capacity for 7,500 tons of beet/day requires around 30 full time equivalents (FTE) during the campaign for transport alone. Of course, all of this depends on the market price of sugar and electricity. However, the new sugar plant requires land for sugar beet production. Therefore, available land for field crop production is decreased, and this influences the capacity of the new plant (balancing loop B1). The sugar beet production area is limited by crop rotation rules (recommended share of sugar beet in the crop rotation is $20 \%$, higher shares can cause a decrease in yields and sugar content, and can also lead to more serious pest problems). There is also balancing loop B2 with a variable sugar price, which influences the decision-makers. Namely, increased sugar production and/or import of sugar from a free market leads to a decrease in sugar price negatively influencing the sugar beet prices, which can negatively impact the farmers' motivation for sugar beet growing and consequently result in the decrease of land for the sugar crop area and also decrease production level. These two loops, B1 and $\mathrm{B} 2$, are the basis for the planning of potential capacity of both plants. Biological remains (such as green mass and soil that come to the factory with the beet) can affect the environment; therefore a biogas plant that results in electric energy and additional employment opportunities should be built. In this manner, the negative influence on the environment is decreased (balancing loop B3). The reduction of the negative effect on the environment through loop B3 is also expressed in:

- The use of waste lime (a result of the carbonation sugar-cleaning process in one of the stages of sugar production). Waste lime is one of the most effective lime-based fertilizers, and, importantly, its use by sugar beet-producing farmers contributes to a decrease in soil acidity.

- The remains from the biogas plant can also be used as fertilizer. Furthermore, biogas production is usually combined with liquid manure from animal farms. Liquid manure is the source of methane $\mathrm{CH}_{4}$ that is an even more damaging green-house gas than carbon dioxide $\left(\mathrm{CO}_{2}\right)$. In the biogas plant, the methane (produced through methagenic fermentation in the biogas plant reactor) is transformed to less damaging carbon dioxide 
and water in the gas engine powering the electric generator.

Figure 1 is qualitative, and provides important causal loop relationships between relevant factors when deciding on investment. This can be incorporated into the holistic model in Figure 1; however, several other elements must be considered in further model development, such as annual climatic factors, world sugar production, and price. In the next chapter we focus only on sugar production; because of investment limitation, a biogas electrical plant is on our long-term planning horizon.

\section{SD Model of sugar production}

Figure 2 shows the CLD as the basis for the SD model of the sugar beet industry. We used the standard stock-inventory model as a basis.
Figure 2 shows the CLD of production capacity, estimated demand, and stock of sugar production. The primary driving variable in the model is »demand «, which determines the operation of the entire system. According to the »demand «, the sales diminish the »sugar stock«. In contrast, the »demand « influences the »desired production«. One may observe the delay mark from »demand « to »desired production «; if »demand « increases, then »desired production « is higher than it would otherwise have been. Here, it is important that the impact of the delay from »demand « to »desired production « is as short as possible, and also that the »demand « estimates are correct. Another link that influences »desired production « is »sugar stock « control link. If the »sugar stock « increases, the »stock shortage«, which is dependent on the »desired stock«, decreases. Here, we compare the »desired stock « and actual stock, which is named »sugar stock« in our case. If the »stock shortage« increases,

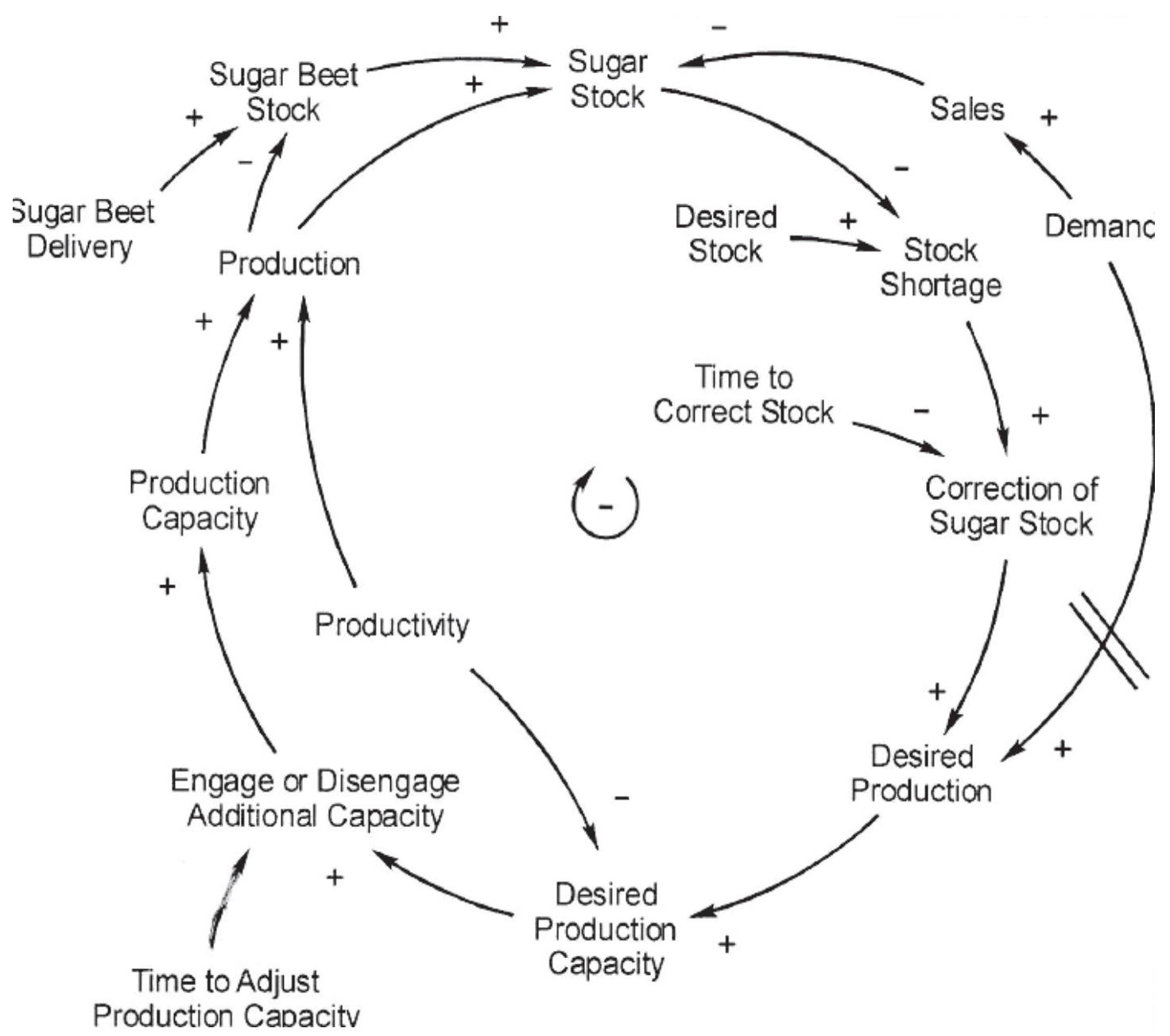

Figure 2: CLD of production capacity, estimated demand and stock of sugar production 
the »correction of sugar stock « also increases. The response is determined by the »time to correct stock «; if the »time to correct stock « is longer, it will take longer to perform proper control action. The »correction of sugar stock« positively influences the »desired production«, which is the sum of »demand" values and the shortage of stock in our case, whereby proper control action is determined by the »correction of sugar stock «. »Desired production« determines the $»$ desired production capacity«, which is dependent on the "productivity« of the production means. If the "productivity« is greater, fewer production means are required, therefore the »desired production capacity « is lower. If the »desired production capacity « increases, the »engagement or disengagement of additional capacity « is higher than it would otherwise have been. This is also dependent on the »time to adjust production capacity«. »Engagement or disengagement of additional capacity « determines the "production capacity«, which determines the "production $"$ by additional consideration of »productivity«. The »sugar beet stock « is dependent on the »sugar beet delivery«, which increases the "sugar beet stock «, and, conversely, the intensity of the "production« decreases the »sugar beet stock«.

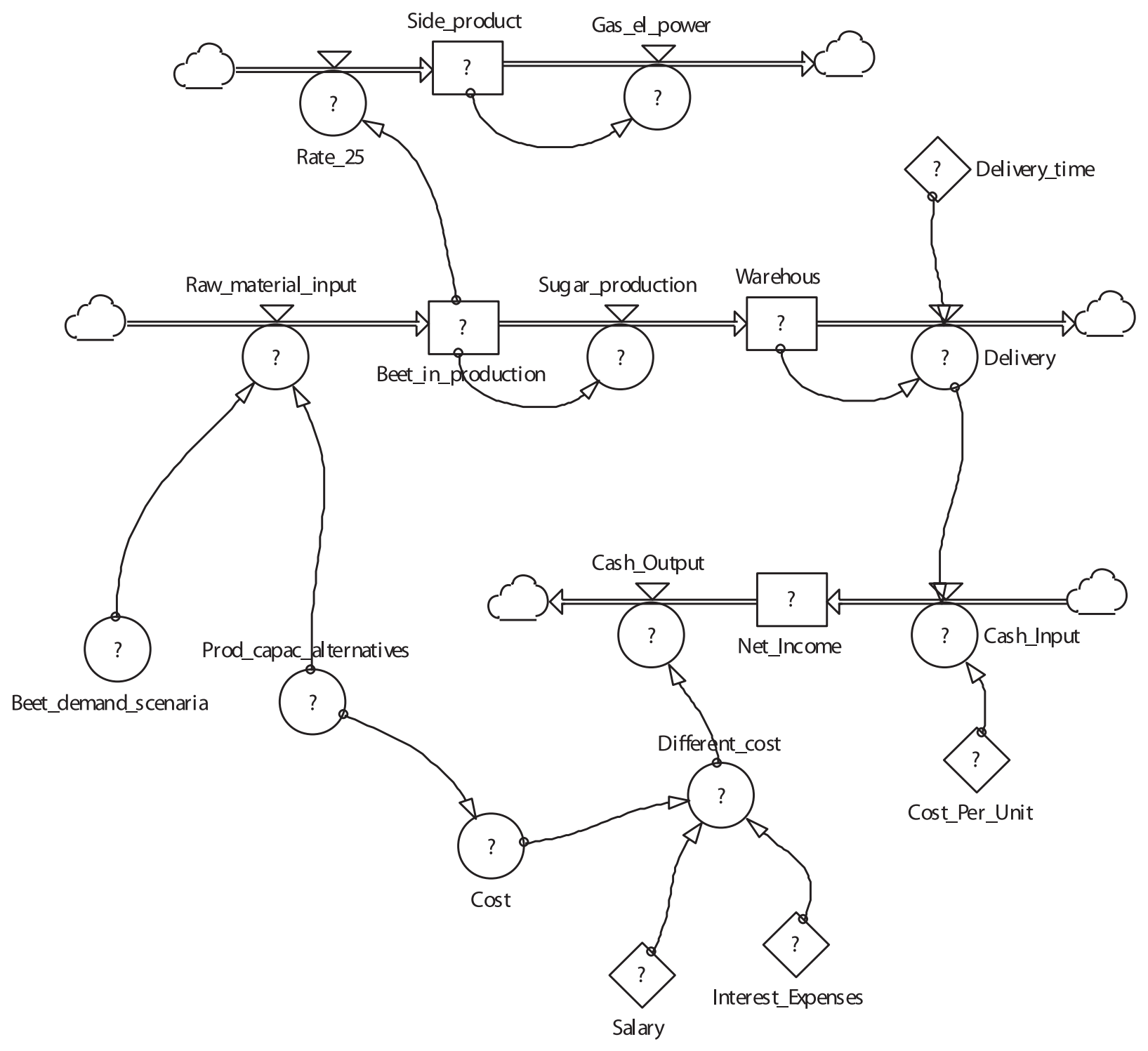

Figure 3: Preliminary SD model for investment decision support 
»Sugar stock « is therefore dependent on the "production", as well as on the capability to provide proper "sugar beet stock « supply. The structure represents a negative feedback loop with reference, which is primarily determined by the sugar $»$ demand $\ll$.

The system can be modeled with a simple SD model, as shown in Figure 3.

The financial aspects of a new investigation were modeled in Powersim, as a continuous simulation model based SD methodology. The model will be used to test different business strategies in order to define the appropriate mix of price and costs for anticipated market demand with respect to production constraints.

The difference equation for net income $(N I)$, from Figure 3, takes the following form:

$N I_{i j}(k+1)=N I_{i j}(k)+\Delta t\left(C I_{i j}(k)-C O_{i j}(k)\right)$

where, $N I_{i j}(k+1)$ represents net income at a future time; $N I_{i j}(k)$ is net income at the present time for the j-th alternative (type of technology) at the i-th scenario (Market demand); $\Delta t$ is the solution time interval set to the value of 1 month, $C I_{i j}(k)$ is cash input, $C O_{i j}(k)$ is cash output and $k$ $=0,1,2, \ldots$ represents simulation time. Cash input and cash output are defined as follows:

$$
\begin{aligned}
& C I_{i j}(k)=C P U_{i j} * S D_{j} \\
& C O_{i j}(k)=I E_{j}+S_{j}+P C_{j}+\text { Others }
\end{aligned}
$$

where $i, j$ represents the $j$-th alternative and the $\mathrm{i}$-th scenario, $P P U_{i j}$ is price per unit, which is determined according to the market,

$S D_{j}$ is rate of sugar delivered,

$I E_{j}$ is interest expenses and other financial expenses, which represent different investment arrangements of the production alternatives, such as depreciation, administrative expenses, fixed costs, etc.). With adequate modification equation 1 will be used as decision criteria for analysis.

An expert group should determine unit sale price and market demand function, according to the different production scenarios and properties of alternatives. Scenarios are defined as a set of parameters: unit sale price, unit production costs, market demand, and other operating expenses. Market demand was formulated as a prediction function of demand and existing orders, which was determined by the regional expert group in the form of external scenarios. In equation 2, we did not consider invest into gas electrical plant and humus production.

\section{Conclusions}

In this paper, we attempted to employ a preliminary SD model in order to simulate the sugar beet processing process. The presented SD model enables simulation of different pol- icies, and it is comprehensible to a wide range of users in the decision-making process. The holistic model presented main feedback loops and dynamics of main elements in the case of regional investment in the sugar industry. This way we can simulate effects of the investment into sugar factory on regional economy (work force) and environment. The factory model considered the specifics of the beet processing, which are a) limited period of beet processing, and b) initial adjustment to the production capacity at the start of the production season. In addition, the main feedback loops, which enable proper control, were identified, and this is important for the management of the considered system. Further consideration must be given to the interaction between elements in the main feedback loop in the system, which determines the system performance and provides the means for proper definition of control strategy. The main advantage of the SD model is its capability to assess strategy changes and the response of target variables over time. Such model can be useful tools for decision-makers to use in sugar-beet processing for the efficient organization of regional sugar industry systems. Likewise, the consideration of longer time periods and sugar prices will be accounted for in further model development.

\section{Literature}

Gaucher, S., Le Gal, P. Y., \& Soler G. (2003). Modelling Supply Chain Management in the Sugar Industry. Proceedings of the South African Sugar Technologists' Association (77): 542 - 554.

Gohin, A., \& Bureau J.C. (2006). Modelling the EU sugar supply to assess sectoral policy reforms. European Review of Agricultural Economics, 33(2), 223-247, http://dx.doi. org/10.1093/erae/jbl006

Jones, P.D., Lister, D.H., Jaggard, K.W., \& Pidgeon J. D. (2003). Future climate impact on the productivity of sugar beet (Beta vulgaris L.) in Europe. Climatic Change, 58(1-2), 93-108, http://dx.doi.org/10.1023/A:1023420102432

Forrester, J.W. (1958). Industrial Dynamics: A Major Breakthrough for Decision Makers. Harvard Business Review, 36(4), 37-66.

Forrester, J.W. (1994). System dynamics, systems thinking and soft OR. System Dynamic Review, 10(2-3), 245-256, http://dx.doi. org/10.1002/sdr.4260100211

Henke, S., Bubník, Z., Hinková, A., \& Pour V. (2006). Model of a sugar factory with bioethanol production in program Sugars ${ }^{\mathrm{TM}}$. Journal of Food Engineering, 77(3), 416-420, http://dx.doi.org/10.1016/j.jfoodeng.2005.07.007

Polet, Y. (2012). EU 27 Sugar Annual Report 2012. USDA Foreign Agricultural Service, pp. 13 Retrieved February 7, 2014 from http://gain.fas.usda.gov/Recent\%20GAIN\%20Publications/ Sugar\%20Annual_Brussels\%20USEU_EU-27_4-27-2012. pdf

Ćurčić, Ž., Kovačev, L., Danojević, D., Nagl, N., \& Čačić N. (2009). Dostignuća i očekivanja u oplemenjivanju šećerne repe [Achievements and expectations in sugar beet breeding]. Zbornik radova Instituta za ratarstvo $i$ povrtarstvo, 46(2), 285-292. 
Martinez-Moyano, I. J., \& Richardson, G. P. (2013). Best practices in system dynamics modeling. System Dynamics Review, 29(2), 102-123, http://dx.doi.org/10.1002/sdr.1495

Rehan, R., Unger, A. J. A., Knight, M. A., \& Haas, C. T. (2014). Financially sustainable management strategies for urban wastewater collection infrastructure-Implementation of a system dynamics model. Tunnelling and Underground Space Technology, 39, 102-115, http://dx.doi.org/10.1016/j. tust.2012.12.004

Rozman, Č., Pažek, K., Kljajić, M., Bavec, M., Turk, J., Bavec, F., ... \& Škraba, A. (2013). The dynamic simulation of organic farming development scenarios - A case study in Slovenia. Computers and Electronics in Agriculture, 96, 163172, http://dx.doi.org/10.1016/j.compag.2013.05.005

Rozman, Č., Pažek, K., \& Petek J. (2013). Študija izvedljivosti projekta pridelave in predelave sladkorne pese. [Feasibility study of sugar beet production and processing]. Predstavitev študije za javnost, Hoče, Fakulteta za kmetijstvo in biosistemske vede, Univerza v Mariboru, Hoče January 24, 2013, http://www.sladkornapesa.si/dmdocuments/Studija $\% 200 \% 20$ izvedljivosti\%20projekta.pdf

Steinrücken, G. (2005). Prospects in sugar beet breeding. In: Biancardi, E., Campbell, L.G., Skaracis, G.N., \& De Biaggi, M. (Eds.), Genetics and Breeding of Sugar Beet (pp. 309323). Enfield, NH: Science Publishers Inc.

Stöckle, C.O., Donatelli, M., \& Nelson R. (2003). CropSyst, a cropping systems simulation model. European Journal of Agronomy, 18(3), 289-307, http://dx.doi.org/10.1016/S11610301(02)00109-0

Tzilivakis, J., Jaggard, K., Lewis, K.A., May, M., \& Warner D.J. (2005). Environmental impact and economic assessment for UK sugar beet production systems. Agriculture, Ecosystems \& Environment, 107(4), 341-358, http://dx.doi.org/10.1016/j. agee.2004.12.016

Vandendriessche, H. J., \& Van Ittersum M.K. (1995). Crop models and decision support systems for yield forecasting and management of the sugar beet crop. European Journal of Agronomy, 4(3), 269-279.

Črtomir Rozman achieved his Ph.D. at University of Maribor, Faculty of Agriculture. He is active as Full Professor for Farm management in the Department for Agriculture Economics and Rural Development (Faculty of Agriculture and Life Sciences, University of Maribor). His research includes development of decision support systems for farm management (simulation modeling, multi criteria decision analysis, machine learning) and economics of agricultural production. He is also involved in teaching activities as Head of Department and as thesis supervisor at post graduate study programs and multiple national and international research projects. $\mathrm{He}$ is author or coauthor of 60 scientific papers including 25 papers in journals with impact factor.

Andrej Škraba obtained his Ph.D. in the field of Organizational Sciences from the University of Maribor. He works as a researcher and assosiated professor at the Faculty of Organizational Sciences in the Cybernetics and DSS Laboratory. His research interests cover modeling and simulation, systems theory and decision processes. He is a member of System Dynamics Society and SLOSIM.

Karmen Pažek achieved her Ph.D. at University of Maribor, Faculty of Agriculture in 2006. She is active as Associated Professor for Farm management in the Department for Agriculture Economics and Rural Development on Faculty of Agriculture and Life Sciences, University of Maribor. Her research includes development of decision support tools and systems for farm management (simulation modeling, multicriteria decision analysis, option models) and economics of agricultural production. She is involved in teaching activities as thesis supervisor at postgraduate study programs and involved in national and international research projects. She is author or coauthor of 41 scientific papers including 19 papers in journals with impact factor.

Miroljub Kljajić completed his Ph.D. at the Faculty of Electronics, University of Ljubljana in 1974. He is a Professor Emeritus at the Faculty of Organizational Sciences in Kranj in the area of Systems Theory, Cybernetics and Computer Simulation. His main fields of research include decision support systems in global e-commerce and methods of modeling and simulation of organizational systems. He has been the principal investigator of many national and international modeling and simulation projects. As author and co-author, he has published more than 30 scientific articles recognized in $\mathrm{SCl}$ with more than 300 citations. 